\title{
Management of native and exotic plant species with edible fruits in a protected area of NW Patagonia
}

\author{
Melina Fernanda Chamorro ${ }^{1 *}$ and Ana Ladio ${ }^{1 *}$
}

\begin{abstract}
Management practices are very sensitive to socio-environmental change and the influence of market society. This case study was carried out in the Cuyín Manzano rural community, situated in a protected area within the North Patagonian UNESCO biosphere reserve. We investigate the differential practices applied by the community with regard to management of native and introduced species with edible fruits using semi-structured and free interviews in 11 homes (80\%). A Participatory Rural Appraisal (PRA) was also performed to validate the field results. The data was analyzed quali-quantitatively, in the latter case with Generalized Linear Models. A total richness of 27 species was found, of which 11 were native and 17 introduced. Native plants were mainly managed by gathering and tolerance, while exotic species were not only harvested, but also protected, sown and transplanted, and plants inherited from forebears were cared for. Management intensity varied according to origin, being greater for the introduced species. In addition, the species of greater cultural importance were also those which experienced a higher number of management practices, with possible processes of incipient domestication being particularly notable for two native plants. Exotic plants have a higher probability of being managed, and with greater intensity, than native ones, even though the latter have had a much longer history of use. Our results show patterns of diversification of edible fruit species through different management practices. For inhabitants, these practices represent significant situations of contact with nature, which enable traditions based on local knowledge to be maintained.
\end{abstract}

Keywords: Biocultural Conservation; Gathering; Diversification; Traditions.

1 INIBIOMA, CONICET, Universidad Nacional del Comahue, Quintral, 1250-8400 San Carlos de Bariloche, Río Negro, Argentina.

* Corresponding author $\bowtie$. E-mail address: MFC (melinachamorro@gmail.com), AL (ahladio@gmail.com)

\section{SIGNIFICANCE STATEMENT}

In this study carried out in a rural community of northwest Patagonia, we show that the inhabitants have developed diverse management practices for native and introduced plants with edible fruits. These reflect cultural heritage processes that favor the cultivation of introduced plants and the gathering of both native and introduced plants for use. Exotic plants currently have a higher probability of being managed, and with greater intensity, than native ones, even though the latter have a much longer history of local use. The construction of an increasingly anthropomorphized landscape is being oriented towards the use of introduced species of great cultural importance. This case study is a clear example of how management practices gradually shape a humanized biodiversity based on history, knowledge, practices and emotions. 


\section{INTRODUCTION}

The role of local management practices employed with useful plants that tend to improve human subsistence has been widely documented, especially in rural and/or indigenous communities that depend directly on their environment (Capparelli et al. 2011; Casas et al. 2007; Parra et al. 2012; Reis et al. 2018). We can define management practices as the use of local ecological knowledge (LEK) on the part of a society with the aim of maintaining or improving the abundance, diversity, and/or availability of natural resources of interest in an ecosystem (Fowler and Lepofsky 2011). These consist of the interventions, transformations, strategies, or deliberate decisions implemented in a plant ecosystem, affecting its components, functions, and even its emerging properties, in order to make use of, and at the same time preserve or recover the resources on different temporal, spatial, and social scales (Casas et al. 1996, 1997).

Determining how human beings have shaped a large part of what we know as "nature" is currently one of the great challenges of ethnobiology. Several authors have pointed out the significance of considering these practices, given that they constitute conscious transformative activities that also lead to a process of domestication of the landscape (Clement 1999). Domestication of the landscape we understand to mean how the landscape has been molded to suit the needs and ways of the societies who inhabit it (Ladio and Molares 2017). This implies shaping the physical and biological components, as well as their interrelations and processes, with the purpose of satisfying the material and spiritual needs of the culture. Domestication at the level of plant populations implies processes of morphological and physiological differentiation, where artificial selection, genetic drift, gene flow and endogamy all come into play, at the hands of human beings (Casas et al. 2017).

For some time now, a special effort has been made to develop ways of classifying and therefore describing plant management practices. A continuum is recognized which includes everything from gathering to horticultural practices with domesticated species (Blancas et al. 2010; Casas et al. 1997; Lins Neto et al. 2014). Among the various types of management practices, in situ practices can be identified, such as: gathering, tolerance (through which a plant is preserved within the peridomestic area) protection from external agents (whether from climatic conditions, pests, or elimination by competitors), promotion, (mainly directed at increasing the population density and availability of a useful species), and cultivation. Among ex situ practices are: cultivation (whether by sowing or reproduction by propagules), and transplantation of the whole plant from its natural habitat to a managed area (Blancas et al. 2010). These different management categories, which imply a differential gradient of human intervention, have been shown to be useful as heuristic models to aid understanding not only of processes of species and landscape domestication, but also of the unique links established between societies and edible plants (Aguirre-Dugua et al. 2012; Blancas et al. 2013; Lins Neto et al. 2014; Parra et al. 2010).

The study of management practices for focal species is very important, since it can identify changes at a phenotypic and even genotypic level (Casas et al. 2007; Cruse-Sanders and Casas 2017; Parra et al. 2010). Parra et al. (2012), showed that in the case of the native cactus Stenocereus pruinosus, the gathering and later cultivation of propagules in family vegetable gardens favored selection processes towards sweeter fruits with red, orange and yellow flesh. In addition, greater phenotypic and genetic diversity was found in these gardens than in the wild natural spaces the cactus grows in, showing that the farmers safeguard diversity in their plots (Parra et al. 2010). By means of these practices, these sites act as "biological corridors" sensu Parra et al. (2012), where there is constant gene flow, both because of the action of pollinators and birds spreading seeds, and human intervention.

According to Clement (1999), landscape domestication is directly related to the intensity of management carried out on the species by a society. A gradient of the intensity of management of edible plants is recognized, which depends on several biological, ecological, and sociocultural factors. The productivity and availability of the selected plants is crucial to this gradient, as is their cultural importance from a local perspective. Other determining factors in management intensity are: the amount of energy invested in management, the use of tools or machines, and/or the implementation of organizational rules in the community, among others identified by several authors (Blancas et al. 2013; González-Insuasti et al. 2008; González-Insuasti and Caballero 2007). Furlan et al. (2017) in particular point out that the accumulated number of different management practices carried out on a species is indicative of higher management intensity; therefore, this species experiences greater coevolutionary pressures that could result in incipient domestication, and in an increasingly domesticated landscape.

The relationships formed between people and plants vary according to interaction time, with marked differences between those with prolonged use (native plants) and those introduced later (exotic plants). Schmeda-Hirschmann et al. (2019) have shown the existence of native fruits in Patagonia that were presumably consumed approximately 
10,000 years BP, such as Fragaria chiloensis, Berberis spp., Ribes magellanicum, Ericaceae and Rubus spp. Subsequently, with the arrival of settlers, numerous new plants began to be used, which had such an impact that they even displaced crops of traditional species native to the area (Ladio 2017). Another phenomenon of great importance is that many of the introduced species became wild and began to form an important part of the Patagonian Flora (Ezcurra and Brion 2005). Several of these species are invasive in behavior (Fernández 2007; Zimmermann et al. 2011) and represent an enormous threat to biodiversity (Lockwood et al. 2013; Viña et al. 2019).

Detailed understanding of the range of local management practices used for both native and introduced plants has been lacking in Patagonia until now, and little has been done in other parts of the world (Casas et al. 2017). This means that local practices carried out by indigenous peoples and local communities in the pursuit of maintaining subsistence resources have not been recognized or valued (Sedrez dos Reis et al. 2014). These practices are very sensitive to socioenvironmental change and the influence of a market society (Reyes-García et al. 2013). Therefore, in accordance with Díaz et al. (2018), it is essential to assess and test heuristic models that can be used to rethink different practices and human values with regard to nature. In particular, this case study was performed in the rural community of Cuyín Manzano, part of a protected area and UNESCO biosphere reserve, where tension exists between the authorities and the inhabitants with regard to understanding the landscape management they carry out.

Chamorro and Ladio (2020) have highlighted the role of plants with berries in local diets of Patagonia since ancestral times. However, this living heritage appears to have undergone hybridization processes, such that exotic species play an increasingly significant role. In this work, we will investigate the management practices applied on native and introduced species with edible fruits (berries and other types) in Cuyín Manzano community. Given the different interaction histories of native and introduced plants, we expect to find differential patterns in which: 1 . The cultural importance of native species will be greater than that of introduced species. 2. The types of management practice will be different, such that native plants will be gathered and cultivated, while exotic species will mainly be cultivated. 3 . The total number of management practices carried out for each species will be greater for native species. 4. Patterns will differ between native and introduced species as regards management intensity. Furthermore, given that cultural importance can also be a factor determining the extent to which a plant is managed: 5. The species of greater cultural importance will be managed more intensively.

We will discuss to what degree analysis of the differential use patterns of native and exotic species (including invasive species) has implications as a diagnostic tool for flora management, improving our understanding and management of invasive exotic species. This information is also important for biocultural preservation of the tangible and intangible heritage of the community.

\section{MATERIAL AND METHODS}

\section{Study site}

The fieldwork was carried out in the rural community of Cuyín Manzano (CM), which is located in Nahuel Huapi National Park, (40 $45 \mathrm{~S}$ and $71^{\circ} 10$ $\mathrm{W}), 70 \mathrm{~km}$ from the city of Bariloche. This location lies within the North Patagonian Andean Biosphere Reserve (UNESCO 2010). Climate in the region is temperate-cold and humid, with a Mediterranean precipitation regime, with rains and snow mainly in winter (MAT $7.4^{\circ} \mathrm{C}$ ). The rural community is located in an ecotonal environment between the steppe and forests of Austrocedrus chilensis and Nothofagus spp. The population is of mestizo origin; some individuals are direct descendants of the Mapuche people, while others have mixed ancestry, locally called Criollos (Creoles). Only 13 families currently live in the community, due to strong emigration forces. The economic activity of locals has diversified over time; they work in sheep, goat, and cattle farming, tourism, red deer (Cervus elaphus) sport hunting, handcrafts, and also as employees of the state boarding school in the area and at a private ranch. Historically, Cuyín Manzano had a population of 9000 BP (Hajduk et al. 2008), which predates the creation of the protected area. However, the authorities in charge of the protected area have established restrictions on the number of livestock an inhabitant can have, and/or on the felling of trees. They also regulate the hunting of native and introduced animals. This limits the daily activities that people can carry out and causes disputes in biodiversity management.

\section{Fieldwork}

The fieldwork followed the Code of Ethics of the Ethnobiology Society and the Nagoya Protocol (Argentinian National Law $\mathrm{N}^{\circ}$ 27246). We first explained the aims of the research to each family, then after obtaining their consent the family decided who would be interviewed. Verbal individual informant consent was also requested prior to each interview. During the first phase of the study we visited families informally, in order to establish a base for the questionnaire de- 
sign. In the second phase we asked participants to list all the plants they used, which enabled us to produce a list of the most commonly used edible fruits (wild and cultivated) that grew in the area (Albuquerque et al. 2010). In the third phase of the research we used the semi-structured questionnaire to collect data on the management practices used with each species cited, and information about their gathering sites. In addition, we collected data on general concepts and activities related to the management of edible plants. The local people were able to contribute their accounts of events and experiences through participant observation and open and in-depth interviews which were carried out with most of the adult population. The author of each statement is identified with initials to preserve their identity. A census of the population was performed which included 11 households. Only one member of each household generally took part in this study, but in a few cases other family members also participated. Due to access difficulties, two households with one or two inhabitants were not included. The interviewees were aged from 31- 67 years old; $36 \%$ of participants were female and $54 \%$ male.

A community workshop was held after the interviews in order to corroborate which plants were of great cultural importance in the community, and to share the results of the study. This event was attended by 23 adults and 10 children, including teachers, the doctor and the local health worker. Participatory methods as described by Sieber et al. (2014) were used during this meeting. In particular, Participatory Rural Appraisal (PRA) was carried out through a collective discussion session, during which images of all the species cited in the interviews were used as a visual resource to stimulate the interchange of knowledge. The interaction was based on an open framework which promotes focused, conversational, two-way communication. The most significant accounts that complemented and validated the importance of the interview results were paid special attention to. All species were mentioned by the locals using their common names, and then identified taxonomically. Reference materials were collected during walking tours with informants. Native and exotic species were identified using field herbariums and materials from the Herbarium of the INBIOMA Ethnobiology Group, which were also complemented by photographs. Native species were defined here as plants whose origin is central or southern Argentina, below $35^{\circ}$ southern latitude, and exotic species were those which did not fulfill this condition. The specimens were deposited in the Herbarium of the INBIOMA Ethnobiology Group (voucher numbers can be seen in Table 2). The nomenclature used was adapted to The Plant List (www.theplantlist.org). Fruit type was classified following Correa (1998, 1988,
1984, 1971). Exotic invasive species in PNNH and surrounding areas were also identified according to the Biodiversity Information System of Argentina (https://sib.gob.ar/especies). Invasive plants are naturalized species that produce reproductive offspring, often in very large numbers, thus having the potential to spread over a considerable area and impact negatively on native plants (Richardson et al. 2000).

\section{Assessment of management practices}

Considering local accounts, and with the objective of making local practices more visible, the practices were later categorized with a modification of the Casas et al. (1996) and Blancas et al. (2010) classification, as follows: Gathering: the practice of gathering fruits directly from natural populations with no clear history of domestication by inhabitants. Tolerance: when clearing land for houses, or the surrounding area, species with edible fruits are left standing. Protection: protection from specific external biotic and abiotic factors, for certain plants. Sowing: sowing of seeds or reproduction from vegetative parts. Transplantation: moving a young plant or a purchased seedling to a new place. The main change to this classification was the addition of the "Care of inherited plants" group, which refers to the action of preserving fruit plants that were cultivated initially by parents or grandparents. According to our criteria and that of our participants, this category presents a management method that differs from the previous ones.

Determination of the types of management practice used with each species with edible fruits in Cuyín Manzano was based on the emic distinction (from the perspective of the locals), and from participant observation carried out in the field.

\section{Data Analysis}

The information compiled from the interviews and the workshop was analyzed and first interpreted qualitatively. In addition, the data were analyzed quantitatively, reinterpreting the information from the fieldwork, and then analyzed statistically (See Supplementary material).

The total richness of ethnospecies is described, and according to their biogeographical origin; also shown is whether they were found in wild environments or not, and the type of management practice they received. The following variables were assessed in order to compare the management practices applied on native and exotic species with edible fruits:

Variables:

Origin: Native or Exotic. Depending on whether the species is native to Argentina or not (Ezcurra and 
Brion 2005).

Consensus of use: $\mathrm{CU}=\mathrm{FC} / \mathrm{N} \times 100$, where $\mathrm{FC}$ $=$ the frequency of citation of the species and $\mathrm{N}=$ the total number of informants. This index is mainly employed in use- pattern analysis of ethnobotanical data, in order to evaluate cultural importance considering the consensus among participants regarding the species used (Cornara et al. 2014; Molares and Ladio 2009; Tardío and Pardo-De-Santayana 2008).

Management practice (categorical): We distinguished the presence and absence of these practices for each species: gathering, tolerance, protection, care of inherited plants, sowing, transplantation.

Number of management practices: $\mathrm{NMP}=\sum$ cites for each type of management practice. This was considered an indirect measurement of the total number of management practices used by the entire population.

Number of management practices per species: NMPs $=\sum$ cites for a species (including all types of management practice). This variable shows to what extent a species is managed (Furlan et al. 2017).

Intensity of management of a species: $\mathrm{IM}=\sum$ $\mathrm{MF} \times \mathrm{n} / \mathrm{N}$. This index was adapted from that proposed by González-Insuasti et al. (2008), where MF is the form of management that is assigned the following values: 1 for gathering; 2 for tolerance; 3 for protection; 4 for care of inherited plants; 5 for sowing and 6 for transplantation. The number of inhabitants that carry out some type of management is indicated by $\mathrm{n}$. This index subjectively weighs transplantation as the management practice of greatest intensity, with the coefficient 6 .

We used generalized Linear Models (GLM), which have been further developed in recent years for ecology and the analysis of categorical data (Agresti 2007, 2015; Zuur et al. 2009). To analyze data with a count response variable (NMP, NMPs), GLMs with Poisson and negative binomial distributions were used (when the dispersal assumption was not met) (Zuur et al. 2009). For proportion-type data, as with the $\mathrm{CU}$ indexes, GLMs with a binomial distribution were used (Zuur et al. 2009). The Tuckey test was used a posteriori to compare the means (Crawley 2013). The analyses were performed using the "MASS" and "nlme" packages of the R software, version 3.6.0 (R Core Team 2019). Details of the models, parameters and errors can be found in 1. Figures 1, 2 and 5 were drawn up on Microsoft Office Excel 2016, and Figure 6 was generated with the ggplot2 $\mathrm{R}$ package.

The models used to test the hypothesis are presented following (Zuur and Leno 2016) (Table 1).

\section{RESULTS AND DISCUSSION}

\section{Richness of species with edible fruits in Cuyín Manzano}

The total richness ( $\mathrm{R}$ ) was 27 species, corresponding to 28 ethnospecies that formed part of the local landscape. Of these species, 11 were native and 17 exotic (Table 2).

Of the introduced species, 8 grew only if cultivated, 4 only grew wild, and 5 could be cultivated and were also found in wild areas. Among the exotic plants we identified 3 potential invasive species: Rosa rubiginosa, Prunus cerasus, Prunus avium. These fruits were mainly consumed fresh, and in some cases also as jams, desserts, or refreshing drinks and/or infusions.

\section{Pattern of cultural importance}

In disagreement with hypothesis 1 , the CU of native plants was no different to that of exotic species (GLM, $p>0.05$, Additional File 1). The species with highest $\mathrm{CU}$ were Berberis microphylla, Fragaria chiloensis and Aristotelia chilensis, followed by the introduced species Rosa rubiginosa, Malus domestica and Prunus cerasus, among others. These results are in line with the analysis of inhabitants' accounts during the PRA, since these were also the plants that appeared most frequently in the accounts and showed agreement in their valuations as a source of food. 
Table 1. Generalized Linear Models (GLMs) used in the data analysis.

\begin{tabular}{ccccc}
\hline \hline Hypothesis & Model & Distribution & Variable answer & Co-variable/s \\
\hline \hline 1 & $\mathrm{~A}$ & Binomial & CU & Origin \\
2 & $\mathrm{~B}$ & Negative binomial & NMP(natives) & Management practice \\
2 & $\mathrm{C}$ & Poisson & NMP(exotics) & Management practice \\
2 & $\mathrm{D}$ & Negative binomial & NMP(gathering) & Origin \\
2 & $\mathrm{E}$ & Negative binomial & NMP(protection) & Origin \\
2 & $\mathrm{~F}$ & Poisson & NMP(transplantation $)$ & Origin \\
3 & $\mathrm{G}$ & Poisson & NMPs & Origin \\
4 & $\mathrm{H}$ & Binomial & IM & Origin \\
5 & $\mathrm{I}$ & Poisson & NMPs & CU + Origin \\
\hline \hline
\end{tabular}


Table 2. Cuyín Manzano species with edible fruits, ordered according to their CU (Consensus of use) value. Bold type indicates native species, (*) exotic species with invasive potential.

\begin{tabular}{|c|c|c|c|c|c|}
\hline Species & Local name & Family & Voucher & Fruit type & $\overline{\mathrm{CUU}}$ \\
\hline Berberis microphylla G.Forst. & Michay (box-leaved barberry) & Berberidaceae & $284 \mathrm{MC}$ & berry & 100 \\
\hline Fragaria chiloensis (L.) Mill. & Frutilla de campo (wild strawberry) & Rosaceae & $519 \mathrm{MC}$ & conocarpus & 100 \\
\hline Aristotelia chilensis (Molina) Stuntz & Maqui (chilean wineberry) & Elaeocarpaceae & $500 \mathrm{MC}$ & berry & 91 \\
\hline Rosa rubiginosa L.* & Mosqueta (rosehip) & Rosaceae & Ladio 136 & cynorrhodon & 91 \\
\hline Malus domestica Borkh. & Manzano (apple tree) & Rosaceae & $542 \mathrm{MC}$ & orchard & 82 \\
\hline Prunus cerasus L.* & Guindo (sour cherry) & Rosaceae & $507 \mathrm{MC}$ & drupe & 82 \\
\hline Berberis empetrifolia Lam. & Michay de la costa (heath barberry) & Berberidaceae & $501 \mathrm{MC}$ & berry & 73 \\
\hline Sambucus nigra L. & Sauco (elderflower) & Adoxaceae & $516 \mathrm{MC}$ & berry & 73 \\
\hline Berberis serratodentata Lechl. & Michay de la cordillera(holly barberry) & Berberidaceae & $528 \mathrm{MC}$ & berry & 64 \\
\hline Gaultheria mucronata (L.f.) Hook. \& Arn. & Mutilla(prickly heath) & Ericaceae & $505 \mathrm{MC}$ & berry & 64 \\
\hline Prunus avium (L.) L.* & Cerezo (cherry tree) & Rosaceae & $506 \mathrm{MC}$ & drupe & 64 \\
\hline Malus sylvestris (L.) Mill. & Manzana de campo (crab apple) & Rosaceae & $543 \mathrm{MC}$ & orchard & 55 \\
\hline Prunus domestica L. & Ciruelo (plum tree) & Rosaceae & $508 \mathrm{MC}$ & drupe & 55 \\
\hline Rubus idaeus L. & Frambuesa (raspberry) & Rosaceae & Ladio 154 & multidrupe & 55 \\
\hline Cydonia oblonga Mill. & Membrillo (quince) & Rosaceae & $541 \mathrm{MC}$ & orchard & 45 \\
\hline Pyrus communis L. & Pera (pear) & Rosaceae & $546 \mathrm{MC}$ & orchard & 45 \\
\hline Ribes uva-crispa $\mathrm{L}$. & Grosella (gooseberry) & Grosulariaceae & $512 \mathrm{MC}$ & berry & 45 \\
\hline Berberis microphylla G.Forst. & Calafate (box-leaved barberry) & Berberidaceae & $547 \mathrm{MC}$ & berry & 36 \\
\hline Ephedra chilensis C.Presl & Cola de caballo (joint pine) & Ephedraceae & $503 \mathrm{MC}$ & berry & 36 \\
\hline Ribes magellanicum Poir. & Zarzaparrilla, parrilla de campo (wild redcurrant) & Grosulariaceae & $511 \mathrm{MC}$ & berry & 36 \\
\hline Fragaria $\times$ ananassa $($ Duchesne ex Weston) Duchesne ex Rozier & Frutilla cultivada (cultivated strawberry) & Rosaceae & $504 \mathrm{MC}$ & conocarpus & 18 \\
\hline Prunus persica (L.) Batsch var. Pérsica & Durazno (peach) & Rosaceae & $544 \mathrm{MC}$ & drupe & 18 \\
\hline Ribes cucullatum Hook. \& Arn. & Parrilla, zarzaparrilla (redcurrant) & Grosulariaceae & $510 \mathrm{MC}$ & berry & 18 \\
\hline Rubus ulmifolius Schott & Murra (blackcurrant) & Rosaceae & Ladio 137 & multidrupe & 18 \\
\hline Prunus persica var. nectarina (Sol.) Maxim & Pelón (nectarine) & Rosaceae & $545 \mathrm{MC}$ & drupe & 9 \\
\hline Pyrus spp. & Pera que no madura (non-ripening pears) & Rosaceae & - & orchard & 9 \\
\hline Ribes aureum Pursh & Parrilla cultivada (cultivated redcurrants) & Grosulariaceae & BCRUE113 & berry & 9 \\
\hline Schinus patagonicus (Phil.) I.M. Johnst. & Laura & Anacardiaceae & Ladio 104 & drupe & 9 \\
\hline
\end{tabular}




\section{Total management practices}

The most frequent management practices of plants with edible fruits in Cuyín Manzano are gathering ( $45 \%$ of cites), protection $(22 \%)$ and transplantation (21\%), followed by caring for inherited plants $(8 \%)$, sowing $(2 \%)$ and tolerance $(2 \%)$.

\section{Management patterns according to type of practice}

In accordance with hypothesis 2 , the frequencies of the different management practices were different for native and exotic species. As regards native species, gathering was the most frequent practice ( $86 \%$ of cites), but they were also tolerated $(6 \%)$, protected and transplanted (4\%) (Figure 1, GLM and Tukey's test, $p<0.05$, Additional File 1). Exotic species depended equally on protection (31\%), transplantation $(28 \%)$ and gathering $(27 \%)$. To a lesser degree, inherited plants were cared for (11\%) and introduced plants were sowed $(3 \%)$, without significant differences (Figure 1, GLM and Tukey's test, $p<0.05$, Additional File 1).

In addition, it was found that gathering was as likely for native species as for exotic ones (Figure 1, GLM, $p>0.05$, Additional File 1). Concerning tolerance, only one native species was tolerated (Berberis microphylla). With respect to protection, it was found to be 12 times less probable that a native species be protected than an exotic one (Figure 1, GLM, $p<0.05$, Additional File 1). Similarly, a native species was 11 times less likely to be transplanted than an introduced one (Figure 1, GLM, $p<0.05$, Additional File 1). Neither care of inherited plants nor sowing of native plants was recorded.

\section{Differential management of the richness of species with edible fruits}

Figure 2 shows the different management practices and the NMPs value for each plant. Most of the richness managed was gathered, including 19 species (10 native and 9 introduced). Only one native species was also tolerated (B. microphylla). A total of 13 exotic and 1 native species were protected. Eight inherited plant species were cared for and 4 species were sowed, all of which were introduced. In addition, 14 species (13 exotic and 1 native) were recorded as transplanted. Native species (Figure 2a) were mainly gathered, while exotic species (Figure $2 \mathrm{~b}$ ) were associated with a greater variety of management practices.

\section{Management patterns practices accord- ing to the number of practices used on the species}

It was found that the NMPs varied according to the species, but in spite of what was stated in hypothesis 3, native species had a lower NMPs, GLM, $p<0.05$, Additional File 1). The species with highest NMPs were Malus domestica, Berberis microphylla, Prunus cerasus, Fragaria chiloensis, and Sambucus nigra.

\section{Management practices with native species}

The gathering of native species was directly associated with going for walks and taking advantage of the local availability of species, like Berberis microphylla, a common feature of the Cuyín Manzano landscape (Figure 3). One interviewee stated: "When I see a michay, I stop and stay there, eating the fruits, I love them and so do my daughters" (LR). According to interviewees, this practice is associated with moments of recreation, activities that are done with the family, like the case of the heath barberry (Berberis empetrifolia) and prickly heath (Gaultheria mucronata), whose fruits are eaten on the way to the river to swim or while the afternoon away. The same is true for wild strawberries (Fragaria chiloensis), which are found on the sides of pathways or on the mountain trails.

Another three practices complete the range of management types documented for native species. Berberis microphylla was tolerated in domestic and peridomestic spaces, mainly due to the value assigned to its fruits (Figure $3 \mathrm{~b}$ and $\mathrm{c}$ ). In addition, protection and transplanting was recorded for wild strawberries. One family spoke of and showed a photographic record of an experience they had had of cultivating this native species. According to the accounts (LR), the plants were brought from a mountain close to the household and were cultivated in a greenhouse, with results that the inhabitants considered very good with respect to the size and flavor of the fruits; this experience was shared verbally with their neighbors. Another local shared a similar experience: "The children brought a plant to try out and it worked out well" (SC). However, other inhabitants maintained that native plants were very delicate and did not grow if cultivated.

\section{Management practices with exotic species}

The most-gathered exotic species were mainly Rosa rubiginosa, Sambucus nigra and Malus domestica. Rosa rubiginosa is an invasive species that was 


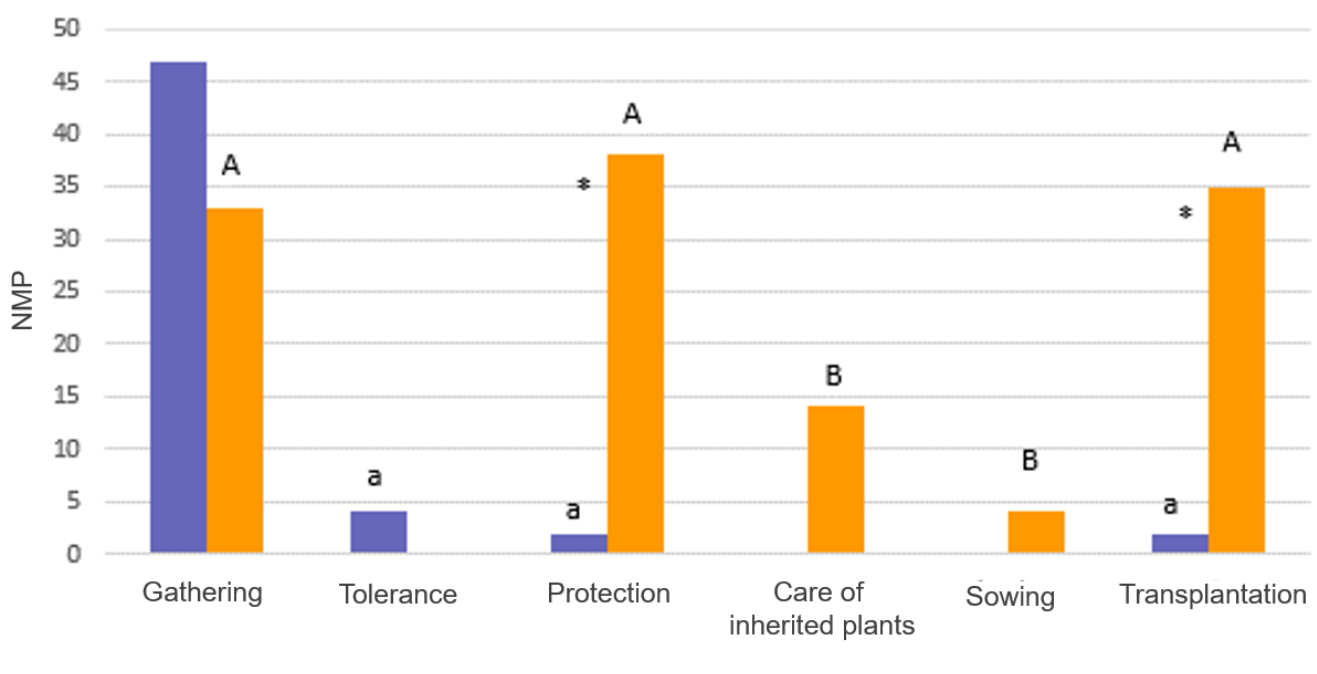

$\square \mathrm{Na}$ Ex

Figure 1. Number (NMP) and types of management practice of native and exotic species with edible fruits in Cuyín Manzano rural community (Patagonia, Argentina). The same letters ("a" for native, "A" and "B" for exotics) indicate no significant differences between practices, Tukey's test $(p<0.054)$. " "*" indicates that differences were found between native and exotic species for a particular practice, GLM $(p<0.05)$.

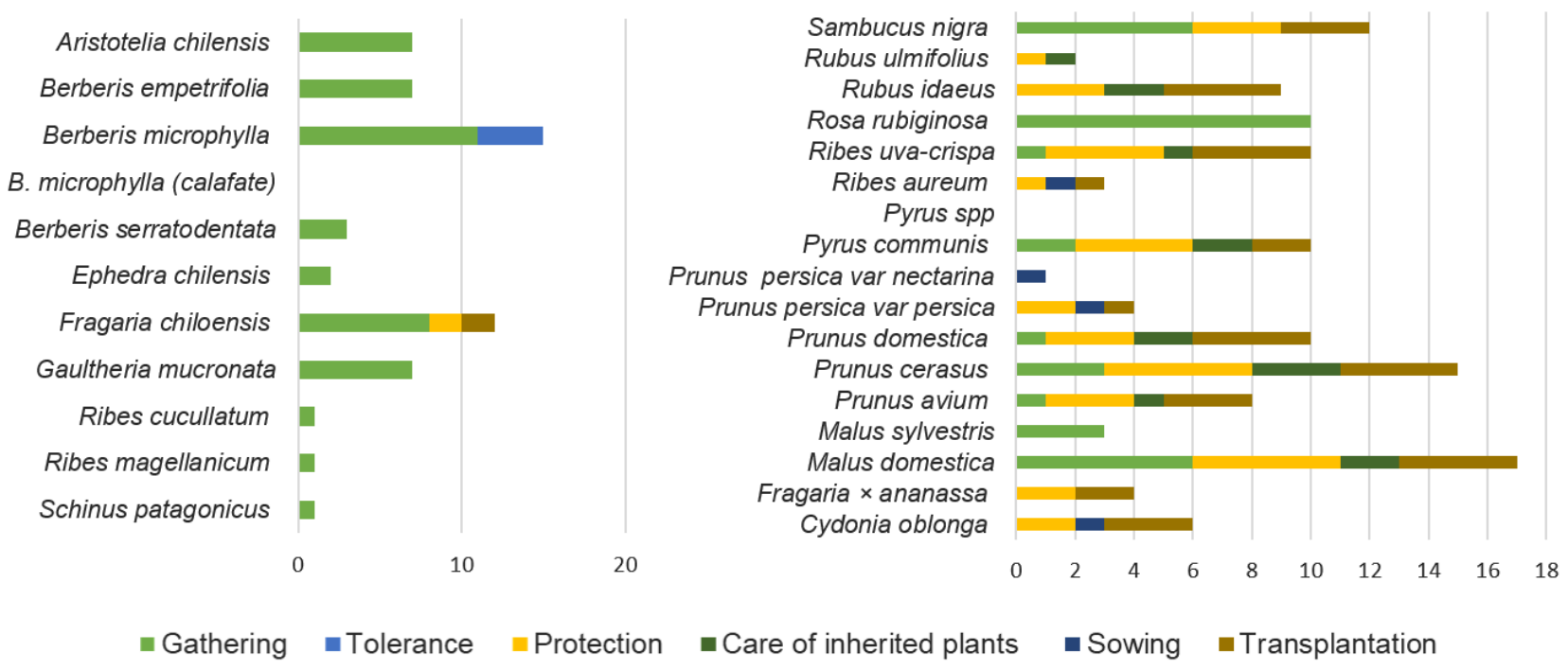

Figure 2. Number of management practices per species (NMPs), for plants with edible fruits in Cuyín Manzano. a) Native species. b) Exotic species.

both observed by the researchers and recorded in the accounts; this plant is bringing about real change in the Cuyín Manzano landscape (Figure 4 a), meaning that it is available in sites close to the households. Sambucus nigra, on the other hand, was gathered from "taperas" (sites that were previously in- habited but are now abandoned), which were pointed out particularly because of the large amount of fruit found there. Unlike the other species gathered, in these cases the fruit was not eaten at once, but was taken home for the preparation of culinary and medicinal preparations, such as rosehip tea and elderberry 

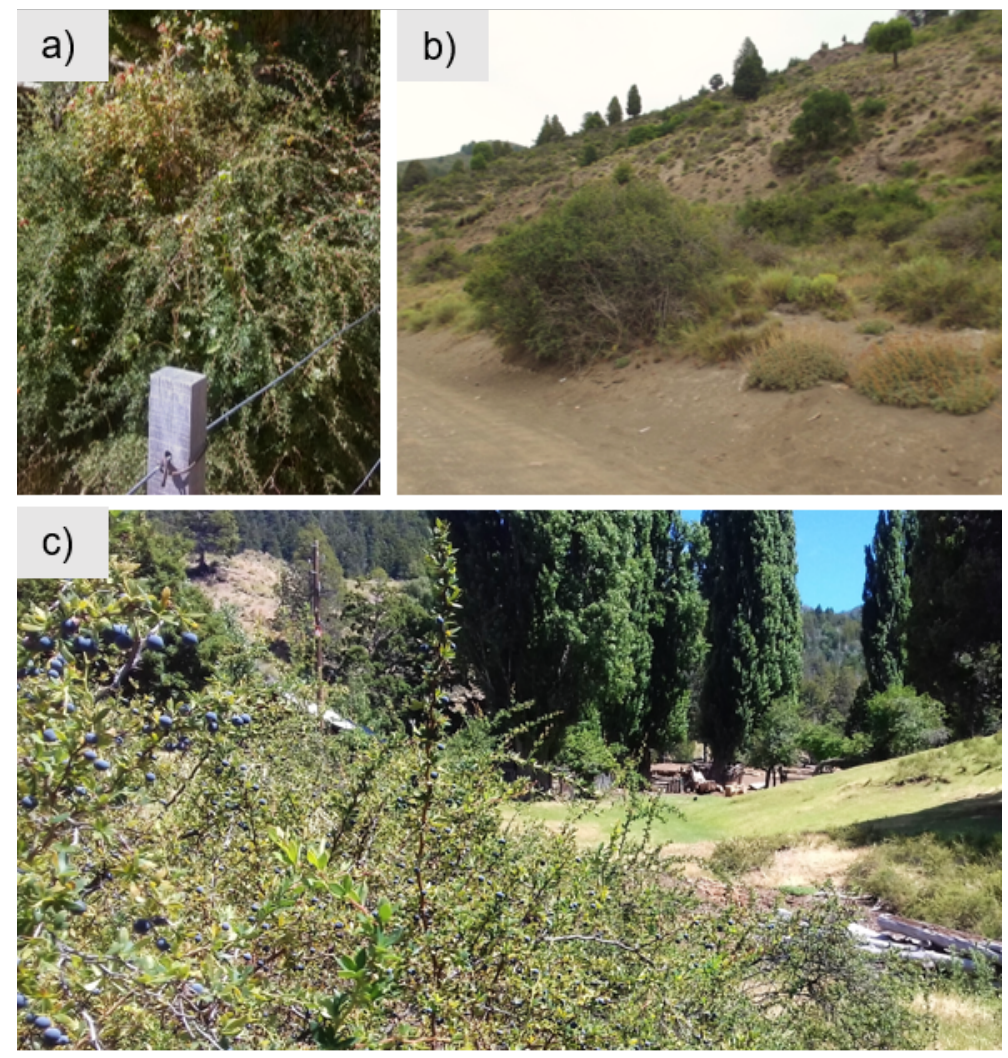

Figure 3. a) Berberis microphylla plant at the roadside, b) and c) plants tolerated within the properties of two local inhabitants.

syrup. Malus domestica, however, had a mixed gathering pattern. Its fruit (Figure $4 \mathrm{~b}$ ) was eaten when gathered, when people were in the fields caring for livestock. These fruits were highly prized due to their capacity to quench thirst and ease hunger, but they were also taken home. Apples in particular were valued as a food, because they were used for the traditional fermented drink, "chicha". This beverage is still being made in the traditional way, and is an activity which involves the whole family, mainly when gathering but also in the preparation process.

The practice of transplanting exotic species was common in this community. To this end, the locals selected a young plant, usually a fruit-bearing tree, from places such as abandoned sites, and took it to their domestic environments. The objective was to increase their supply of fruit (Figure $4 \mathrm{~b}$ and $\mathrm{c}$ ). Another way of obtaining seedlings was to purchase them from garden centers in nearby cities, and to a lesser extent, to receive them through provincial programs for agricultural production. The latter was mostly done with Prunus cerasus and Malus domestica trees (Figure $4 \mathrm{~d}$ and e), but also with Ribes uva-crispa, Rubus idaeus, Pyrus comunis, Cydonia oblonga, Prunus avium and Sambucus nigra, among others.

The protection of exotic species was based on the building of fences to isolate the plants from domestic and wild herbivores, like deer. It also included the use of pesticides and irrigation. Species like Prunus cerasus, Malus domestica, Pyrus comunis, Rubus uvacrispa and Cydonia oblonga were protected. The locals said that the deer were "very greedy" (MC, LC) and liked apples, which is why they had to build fences (and very high ones, because they jump) to stop them reaching the fruit. Another example was the cherries and sour cherries that were affected by a pest (probably the Caliroa cerasi wasp), which is known as the "fruit tree slug". This slug is very common in the area so locals used pesticides, mainly natural ones like ash from fires or wood-burning stoves. In addition, inhabitants had to take action to reduce the effect of climate conditions like wind and frost. To this end, when planting they chose places close to their homes or under a roof.

The care of inherited plants category is of special interest, since its importance as a distinct type of management was evident from informants' accounts. The trees in this group were mainly Prunus cerasus, Malus domestica, (Figure $4 \mathrm{~d}$ and e) Pyrus comunis and Prunus domestica, which were originally grown by parents or grandparents. One of the locals, (SQ, 65), said that his sour cherry trees had been 
planted by his grandparents, which gives an idea of the longevity of these plants (Figure $4 \mathrm{~d}$ ). According to interviewees, these trees produced a large amount of fruit in the past, and had been used by the community to supply the chocolate and jam makers of Bariloche city. This activity was remembered by many of the locals, who used to sell crates of these berries. They also agreed that: "The Cuyín Manzano cherries have a very particular sourness" (TC, MC, DR, SQ).

Apple trees constituted another important case of care of inherited plants (Figure $4 \mathrm{e}$ ). In the areas around the houses large Malus domestica trees could be seen, which were old but still supplied a good amount of fruit. In addition, this species also had few requirements in terms of care, requiring only occasional watering, since some trees "began to dry out", according to interviewees. These species provide a large quantity of fruit for their diet, and all this significance was expressed by the locals: "Today we eat the fruit from the trees that our parents left us, and we will leave plants so that our children and grandchildren can eat" (MC).

The sowing of seeds was not very common in Cuyín Manzano, representing only $10 \%$ of cultivation practices. Specifically, the occasional sowing of seeds from previously ingested fruits was recorded: Prunus persica, P. persica var. nectarine and Cydonia oblonga. It was also documented that in the presence of animal species like deer, which constitute a biological invasion in the region, or goats, which are productive resources, the inhabitants found it increasingly difficult to establish new plantations, "The goat eats anything you plant" (DR).

\section{Management patterns according to management intensity}

It was found that IM varied according to origin, as stated in hypothesis 4. Specifically, IM was generally higher for exotic species than native plants (GLM, $p<0.05$, Additional File 1). Malus domestica, Prunus cerasus and Prunus domestica were some of the species with the highest IM (Figure 5), while Fragaria chiloensis and Berberis microphylla stand out as native species that also experienced high management intensity (Figure 5).

\section{Relation between origin and consensus of use $(\mathrm{CU})$ in the management of a species}

In agreement with hypothesis 5, the NMPs increased with CU (Figure 6, GLM, $p<0.05$, Additional Files 1 and 2). That is to say, a larger number of practices were carried out with species that had higher consensus within the community. However, the effect of origin and CU on the NMPs were independent of each other; i.e., an exotic plant with a high CU had a higher NMPs due to the individual effects, not the interaction between these qualities (origin and cultural importance).

\section{DISCUSSION}

Following the work of Fowler and Lepofsky (2011), our case study in a northwest Patagonian rural community shows the practices used by inhabitants to manage the availability of 27 species with edible fruits. In line with studies carried out in Brazil and Mexico, we found that the culturally more important species for a rural society were associated with diverse management practices, which might lead to processes of incipient domestication in some cases (Lins Neto et al. 2014). However, our analysis comparing the practices used for native and exotic plants enabled us to analyze other patterns which have been scarcely mentioned in the literature until now.

Firstly, to our surprise, we found that in spite of the long history of native plants in the region, exotic plants were playing a very important role. Albuquerque (2006) proposed that when exotic plants are used in medical systems, they enrich the system, occupying niches left free by native plants (diversification hypothesis). In Cuyín Manzano, according to interviewees, exotic plants (cultivated and wild) are distinguished by the larger size of their fruits and greater fruit production than native species. Species like $M$. domestica, $P$. cerasus and $P$. domestica are especially adapted to local environmental conditions; they are vigorous and offer distinctive flavors. In addition, the region has been strongly influenced by European Colonization towards the cultivation of fruit trees from temperate climates (Chamorro and Ladio 2020); for this reason, we propose that these diversification processes have also been fomented over a long period of time.

In Cuyín Manzano, cultural importance is similar for both exotic and native species, but the introduced plants are associated with a larger number of practices and undergo more intense management. That is, this process of diversification leads, secondarily, to greater cultural care. Most of the exotic species need more attention and care than native plants, given that without human intervention it would be difficult for them to survive.

The use of native and exotic plants with edible fruits is associated with different types of management practice. In line with other studies carried out in Patagonia (Ladio and Lozada 2004) and other parts of the world (Abbasi et al. 2013; Avocèvou-Ayisso et al. 2009; Łuczaj and Pieroni 2016; Łuczaj and Szymański 2007; Milanesi et al. 2013; Sansanelli et 

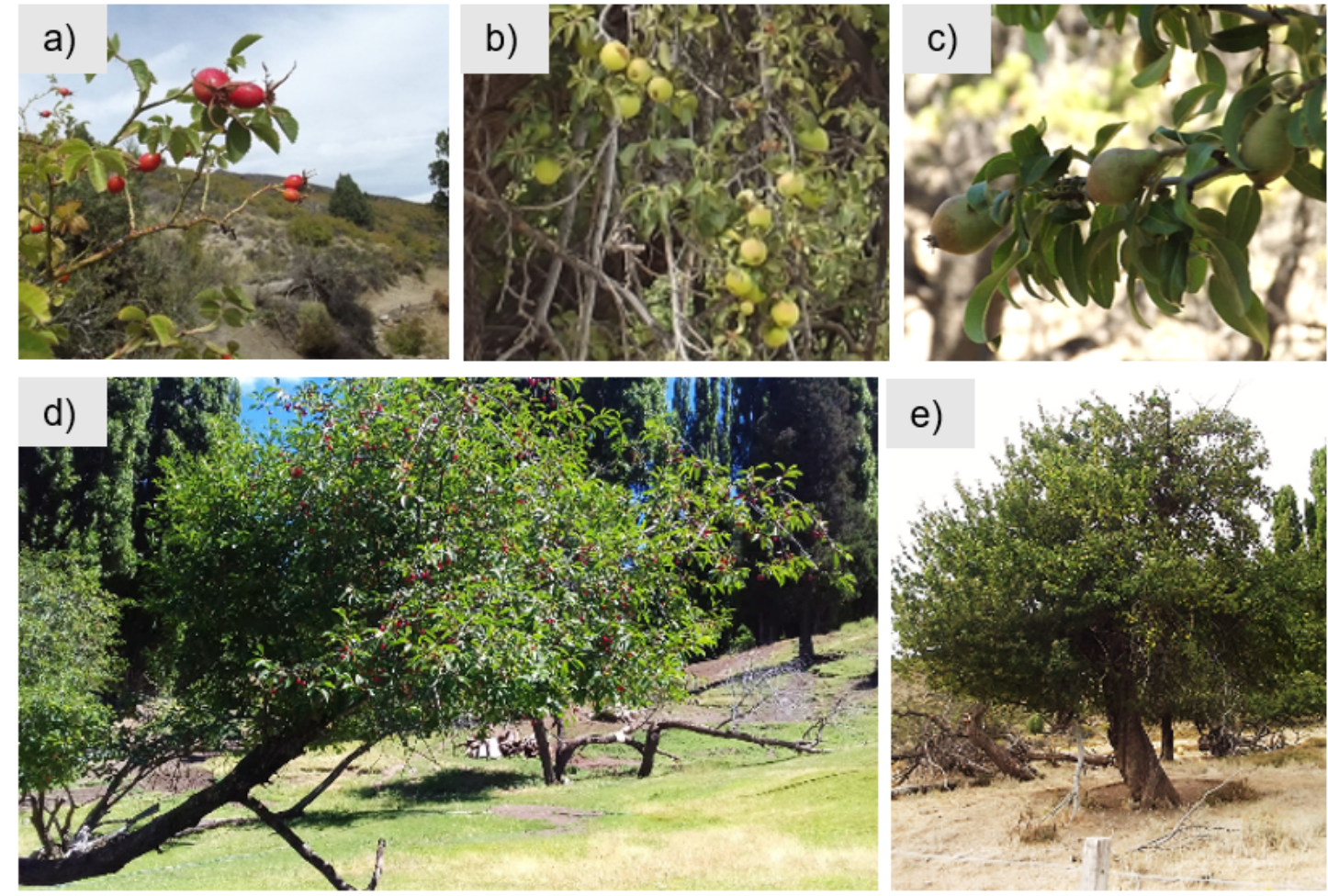

Figure 4. a), b) and c) Rosa rubiginosa, Malus domestica and Pyrus comunis fruits, d) and e) Prunus cerasus and Malus domestica trees in the Cuyín Manzano landscape.

al. 2017; Wadt et al. 2008), gathering is the main method of obtaining native fruits. In addition, the findings show that (albeit for few species) practices towards incipient domestication and cultivation of native plants are being carried out, which had until now been recorded only rarely in contemporary communities in the region. However, the cultivation of native plants has been widely described in rural communities in Mexico (Blancas et al. 2009; González-Soberanis and Casas 2004; Parra et al. 2012) and Brazil (Lins Neto et al. 2014; Sousa Júnior et al. 2016).

The use of exotic species is linked to past cultivation practices, although they are also gathered, even with the same frequency as native plants. Various ecological studies give an account of the prevalence of some exotic and invasive species, such as Rosa rubiginosa, Prunus cerasus, Prunus avium and Malus domestica, within the protected area where Cuyín Manzano is located (Damascos et al. 2005; Ezcurra and Brion 2005; Ladio and Damascos 2000). These plants grow in the wild, mainly as a product of seed dispersal by birds and livestock. The findings shown here are consistent with those of González-Insuasti et al. (2008), who studied the relation between the collection sites of edible species and management practices in Oaxaca, Mexico. The authors found that when people had access to different natural or anthropogenic environments (secondary-growth forests, abandoned cultivation plots) in which the edible resource was abundant, gathering practices were developed in place of species cultivation. Similarly, in Cuyín Manzano the available food resources were being taken advantage of to the fullest.

Sowing and protection practices are mostly associated with exotic species. The low frequency of these practices, and the few species involved, could be related to the fact that native species seem not to require care; they grow on their own and are available to inhabitants in the wilder areas or around their own homes, like the michay. Until now, in Patagonia the protection of B. microphylla and the protection in situ and ex situ of seeds of the native Araucaria araucana have been documented (Ladio 2001; Ladio and Molares 2017). Consequently, the protection and transplanting of the native strawberry in Cuyín Manzano recorded in this study constitute and enrich existing evidence of incipient domestication processes of Patagonian flora.

Description of the protection and sowing of fruit trees enables the current problems in rural areas to be made visible - on the one hand, the characteristic climate of the area (strong winds and frosts) and on the other, pests and herbivores that have increased in recent years. This is consistent with what hap- 
IM

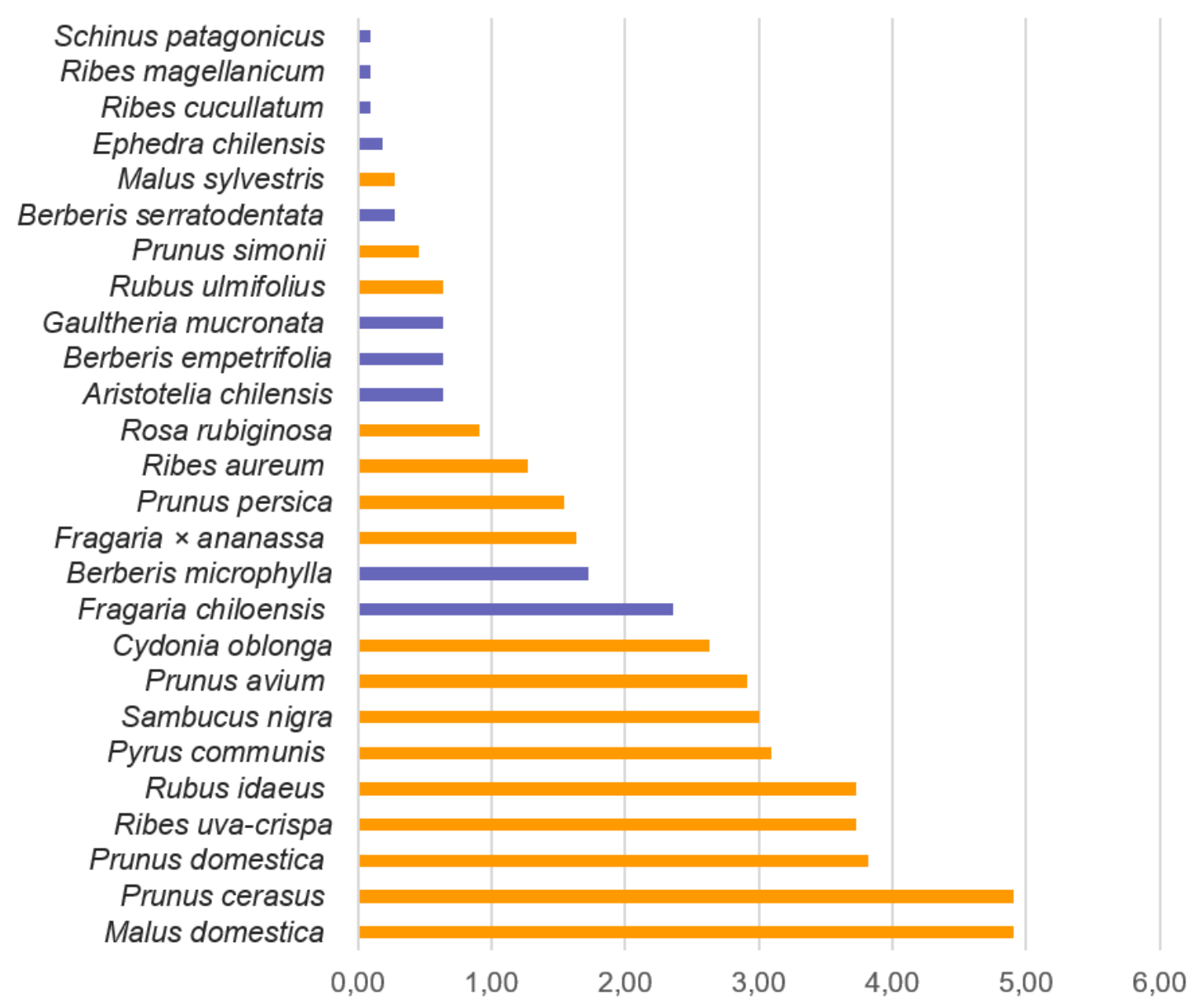

Figure 5. Management Intensity Index (IM) of native and exotic species with edible fruits. Blue: native species. Orange: exotic species.

pens in rural and indigenous communities in Mexico, according to Blancas et al. (2010). In addition, it is noteworthy that transplantation is the most common practice, while sowing is rare. The opposite was found in the Furlan et al. (2017) study in a tropical area, sowing being the main practice used with citrus species in the north of Argentina. One possible explanation could be the strong presence of introduced herbivores that feed on seeds and young trees, a consequence of the livestock paradigms that were established in Patagonia (Ladio and Molares 2017).

The care of inherited exotic plants is very important, and is a clear example of cultural heritage (Maffi 2005) and how the landscape is socially constructed over time. According to Giusti et al. (2018), these practices involving care show a strong connection with nature, where people feel they have a role to play in the conservation of species. The fruits from these plants currently form part of locals' diet, constituting part of their local food (Chamorro and Ladio 2020).
While in this case the care of inherited plants was mostly observed in association with exotic plants, it enables us to comprehend the influence of emotions in the cultural heritage of the landscape, and in the diversification processes mentioned previously.

The findings presented here can contribute to greater understanding of the factors that influence the management intensity exerted on a species. The literature has shown how management intensity is directly linked to social, cultural and technological factors (Blancas et al. 2013; González-Insuasti et al. 2008; González-Insuasti and Caballero 2007). However, this work shows that biogeographic origin is a variable or attribute that can generate differential patterns. For this case study, this condition implies that mainly domesticated species have undergone processes of genetic improvement. Consequently, it can be said that exotic species possess advantages over native species in terms of biological aspects. This is consistent with the proposal of Casas et al. (2017), 


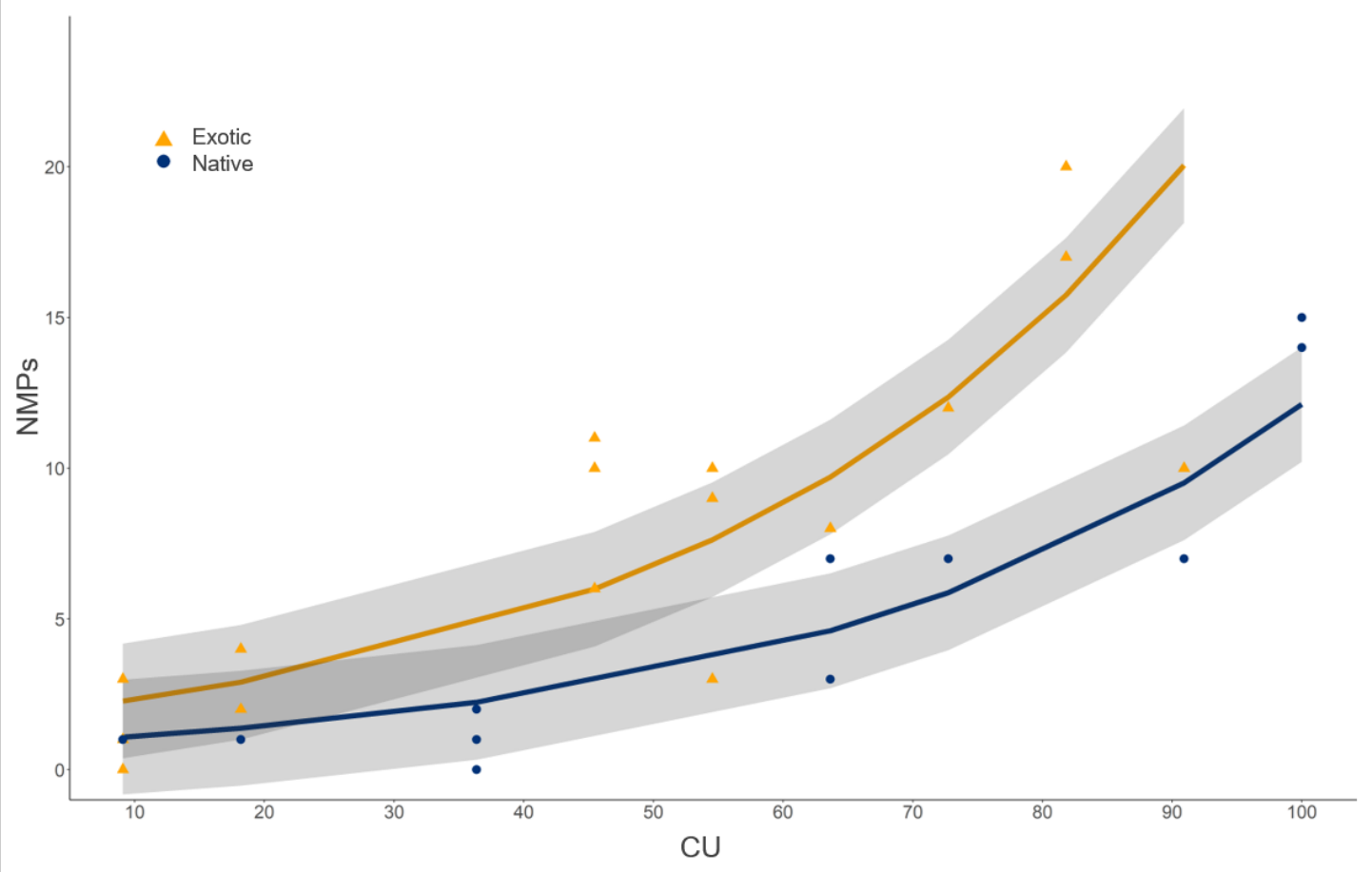

Figure 6. Management Intensity Index (IM) of native and exotic species with edible fruits. Blue: native species. Orange: exotic species.

which describes how the biological traits of plants, the productive cycle, for example, are determining factors in the management intensity of a species.

In this study we highlighted the fact that two native species showed signs of incipient domestication: B. microphylla and F. chiloensis. Incidentally, both are of great cultural importance not only to Cuyín Manzano, but also to Argentine-Chilean Patagonia (Chamorro et al. 2018; Chamorro and Ladio 2020; Ladio 2001; Ladio and Lozada 2004; de Mösbach 1992) and have significant potential as functional foods (Chamorro et al. 2019; Soto-Covasich et al. 2020). Due to domestication of these species, the management exerted on these plants could bring about changes in their phenotypes and/or genotypes, which could be studied in the future.

It appears that mainly introduced plants will design the landscape of Cuyín Manzano. These plants are not only inherited, but also continue to be transplanted and protected, which guarantees their permanence over time. It is known that the management exerted on exotic species in other rural communities allowed the diversification of useful resources, contributing in multiple ways to the daily lives of inhabitants (Lambaré et al. 2015; Stampella et al. 2013). In addition, the idea that these practices are perpetuated over time gives a sense of food security and sovereignty to the present and future generations. In line with the findings of González Insuasti and Caballero (2007) and Blancas et al. (2013) in Mexican rural communities, we found that the practices of higher intensity (such as the sowing and transplanting of exotic plants) are related to a direct increase in the number of inhabitants, and in this way, the availability of resources with a high food value is assured.

The range of practices exerted on the richness of species involves a diversity of ways of relating to nature. In this sense, it is worth noting that the motives for gathering the fruit of native and exotic species also appear to be different. In agreement with the literature, the practice of gathering native species is strongly linked to daily life, as part of walking through the land, and in the search for recreational moments (Grasser et al. 2012; Schunko et al. 2015). In line with what Blancas et al (2013) proposed, the gathering of native species seems to be "opportunistic", while in the case of exotic species it is more a "dedicated harvesting"; a gathering that is planned for production of local food.

In addition, in Cuyín Manzano the gathering of native species seems to be an activity that complements another, like going to the river or hiking. In contrast, the motivation for gathering exotic species is the specific need to obtain food, which has been documented most frequently for this practice (Blancas et al. 2013; Sansanelli et al. 2017). All these activities, 
both for exotic and native species, involve entertainment (such as outings to the river), intimacy (walking alone and finding a plant with fruit), physical activity (walking or riding on horseback), and the senses (mainly taste), among other aspects. These characteristics form part of "significant situations with nature", sensu Giusti et al. (2018); that is, species with edible fruits promote multiple experiences involving connection with the local environment, such that unique links are established with the plants and landscape.

In this work we found that the management practices used with native and exotic plants with edible fruits are very different, and reflect cultural heritage processes that favor the cultivation mainly of domesticated exotic plants, and the use of native and exotic plants obtained by gathering. At the present time, introduced plants have a higher probability of being managed, and with greater intensity, than native ones, although the latter have a much longer history of use. The construction of an increasingly anthropomorphized landscape is being oriented towards the use of exotic species of great cultural importance. Cuyín Manzano is a clear example of how management practices slowly build a humanized local biodiversity, through maintenance of significant situations with nature. While with regard to native plants these significant situations have strong emotional roots, associated with pleasure and wellbeing, the local appropriation of introduced species is also perceived in emotional and significant terms.

In this context, the inherited exotic trees are representative of the living heritage of inhabitants' forefathers; unbreakable links have been forged that lead people to devote special care to these plants. This differential category of management practice, which had not been previously proposed, was very useful in describing the processes of construction of cultural landscapes. Caring for inherited trees ensures that the memory of their forefathers lives on. This information highlights the importance of using flexible heuristic frameworks that allow the inclusion and analysis of categories adapted to local circumstances. In addition, the categories of management practice used here could constitute useful monitoring tools for registering and analytically quantifying changes in practices over time.Similar results have been found with the tree species $A$. araucana and Mapuche children (Canale and Ladio 2020), showing the importance once again of assigning greater value to these situations in terms of biocultural conservation.

This study enables us to draw attention to numerous aspects that can contribute to the conservation of native flora. For example, it is known that gathering non-timber forest products (NTFPs) can affect both the dynamics of the gathered species and the ecosys- tem as a whole (Ticktin 2004). Ticktin (2015) explains that traditional fruit gathering, in general, does not greatly affect the individuals of species with such a long life-span as trees and bushes. This would be the case for the Brazil nut (Bertholletia excelsa) that grows in the Amazon region, but each case should to be studied individually. While the gathering of native fruits in Cuyín Manzano is not associated with commercialization at this time, in other towns of the region $A$. chilensis and $B$. microphylla are in demand for local, national and even international markets (Ochoa et al. 2019). Consequently, due to this increase in market pressure, ecological studies that can contribute to establishing guidelines for gathering are essential.

According to the vast amount of literature on the subject, biological invasions are a major cause of global environmental change due to their effect on both humans and biodiversity (Brondizio et al. 2019). Humans introduce invasive alien species and may facilitate their establishment and spread, which can alter ecosystem services, livelihoods, and human well-being. It is important to highlight that 3 species have invasive potential in this region (Rosa rubiginosa, Prunus cerasus, Prunus avium); the Prunus species in particular are strongly managed, so an increase in the number of individuals in the populated areas of the reserve area is expected.

Shackleton et al. (2019), stated that the role of humans in causing biological invasions is one of the better-researched areas; however, most of these studies do not address the deeper causal practices that link human motivation, behavior and patterns of spread. This research shows that these three species with invasive potential hold great cultural importance. In particular, the guindo (Prunus cerasus) forms part of the history of the Cuyín Manzano area and its families. This shows how exotic species can become iconic elements in the sites they invade, like the case of Cannabis sativa in Jamaica, and other examples given by Nuñez and Simberloff (2005) from other parts of the world. Basically, the cultural value of these invasive species could help us understand their reproductive success.

The role of local land management in facilitating or hindering invasions could be discussed in the light of the "human release hypothesis" (Zimmermann et al. 2014). This hypothesis highlights that an intermediate level of human disturbance or landscape management can influence the abundance of invasive alien species. In this research, the cultural significance of these species and the historical attachment to them displayed by locals could explain and contextualize the results.

The role played by humans in the establishment of exotic species is well known, but local management 
of the landscapes could be a key factor in determining the level of invasion. Zimmermann et al. (2014)'s hypothesis, which suggests that human action affects the abundance of exotic species, and therefore contributes to their invasive character. In a case study carrried out with Rosa rubiginosa (one of the invasive species cited in Cuyín Manzano), these authors compare the plant's behavior in its place of origin (Spain and Germany) with its behavior in Patagonia, Argentina. They found that its invasive behavior could only be explained by the low level of management of the environments it became established in.

Our findings seem to indicate that intermediate levels of management are carried out with the three species, which according to the hypothesis mentioned, may facilitate invasions most. In other words, within this new theoretical/practical framework, in contrast to the conservation paradigms that have long prevailed, promoting a higher level of human management of ecosystems could contribute to halting one of the greatest threats to biodiversity. Further research on the ecological drivers of invasions is needed.

On the other hand, the current role of exotic species (invasive and non-invasive) could also have a beneficial effect on native flora, and people. The richness of introduced species, their high consensus values, and the pattern of management practices found all show that exotic species are made great use of. According to Pfeiffer and Voeks (2008), these exotic species not only enrich local flora, but also enhance cultural traditions, through their inclusion in lexicons, narratives, foods, pharmacopoeias and other tangible and intangible ends. This trend has been pointed out in other places as a process that also leads to a reduction in use pressure for native species (Medeiros et al. 2017; Richeri et al. 2013).

This work identifies practices currently in use with native plants, and which increase their population density. Protection, tolerance and transplantation show how human beings and "wild" plants can coexist in domestic and peridomestic areas, and how in this way the people ensure the survival of these plants and their progeny (Casas et al. 1997). Therefore, further encouragement of these practices would be an excellent strategy for biodiversity conservation.

In particular, management of native and exotic flora not only has implications on an ecological level, but also has an exceedingly high cultural value. For example, the gathering of native species promotes preservation of local knowledge, which is a product of years of experimentation and interaction between people and plants. During this practice, knowledge of the plants, local names, gathering guidelines (should there be any), forms of use and a host of other types of knowledge and experience are all put into action. Furthermore, it has been strongly emphasized that this is particularly important in sites located within a biosphere reserve, like Cuyín Manzano (Bridgewater 2002; Grasser et al. 2012; Schunko et al. 2012). Perpetuation of these cultural practices favors preservation of local ecological knowledge, which is essential considering the scenarios of socioenvironmental change that humanity is currently having to face (Bvenura and Sivakumar 2017; Grasser et al. 2012; Ladio 2001).

\section{CONCLUSION}

In this work we found that the management practices used with native and exotic plants with edible fruits are very different, and reflect cultural heritage processes that favor the cultivation mainly of domesticated exotic plants, and the use of native and exotic plants obtained by gathering. At the present time, introduced plants have a higher probability of being managed, and with greater intensity, than native ones, although the latter have a much longer history of use. The construction of an increasingly anthropomorphized landscape is being oriented towards the use of exotic species of great cultural importance. Cuyín Manzano is a clear example of how management practices slowly build a humanized local biodiversity, through maintenance of significant situations with nature. While with regard to native plants these significant situations have strong emotional roots, associated with pleasure and wellbeing, the local appropriation of introduced species is also perceived in emotional and significant terms.

In this context, the inherited exotic trees are representative of the living heritage of inhabitants' forefathers; unbreakable links have been forged that lead people to devote special care to these plants. This differential category of management practice, which had not been previously proposed, was very useful in describing the processes of construction of cultural landscapes. Caring for inherited trees ensures that the memory of their forefathers lives on. This information highlights the importance of using flexible heuristic frameworks that allow the inclusion and analysis of categories adapted to local circumstances. In addition, the categories of management practice used here could constitute useful monitoring tools for registering and analytically quantifying changes in practices over time.

\section{ACKNOWLEDGEMENT}

We are profoundly grateful to the inhabitants of Cuyín Manzano for their kindness in sharing their knowledge with us, and for their hospitality. We would also like to thank Antonio and Marcos Bergant 
for their contribution as field assistants. Thanks are due to Cecilia Ezcurra for the taxonomic determination of the pest affecting the guindo, and Florencia Baudino, Ramiro Rippa and Lucía Zamora for their assistance with the statistics. The authors also acknowledge with appreciation the constructive comments made by the anonymous reviewers on the earlier version of this paper. This investigation was supported by the Consejo Nacional de Investigaciones Científicas y Técnicas (CONICET) of Argentina (PIP 0723) and by the Centro de Investigación y Extensión Forestal Andino Patagónico (CIEFAP).

\section{DATA AVAILABILITY}

The data used to support the findings of this study are available from the corresponding author upon reasonable request.

\section{CONFLICT OF INTEREST}

The authors have no conflicts of interest to declare.

\section{CONTRIBUTION STATEMENT}

Conceived the idea presented: AL

Carried out the experiment: MFC

Carried out the data analysis: $\mathrm{MFC}, \mathrm{AL}$

Wrote the first draft of the manuscript: MFC, AL

Review and final writing of the manuscript: AL, MFC Supervision: AL

\section{REFERENCES}

Abbasi AM, Khan MA, Khan N, Shah MH (2013) Ethnobotanical survey of medicinally important wild edible fruits species used by tribal communities of Lesser Himalayas-Pakistan. Journal of Ethnopharmacology 148:528-536

Agresti A (2007) An introduction to categorical data analysis. Second ed. Jhon Wiley and Sons, New Jersey

Agresti A (2015) Foundations of linear and generalized linear models. Jhon Wiley and Sons, New Jersey

Aguirre-Dugua X, Eguiarte LE, González-Rodríguez A, Casas A (2012) Round and large: Morphological and genetic consequences of artificial selection on the gourd tree Crescentia cujete by the Maya of the Yucatan Peninsula, Mexico. Annals of Botany 109:1297-1306
Albuquerque UP (2006) Re-examining hypotheses concerning the use and knowledge of medicinal plants: a study in the Caatinga vegetation of NE Brazil. Journal of Ethnobiology and Ethnomedicine 2:1-30

Albuquerque UP, Paiva de Lucena RF, Cruz da Cunha LVF (Eds) (2010) Métodos e técnicas na pesquisa Etnobiológica y Etnoecológica. NUPEEA, Recife

Avocèvou-Ayisso C, Sinsin B, Adégbidi A, Dossou G, Van Damme P (2009) Sustainable use of nontimber forest products: Impact of fruit harvesting on Pentadesma butyracea regeneration and financial analysis of its products trade in Benin. Forest Ecology and Management 257:1930-1938

Blancas J, Casas A, Lira R, Caballero J (2009) Traditional Management and Morphological Patterns of Myrtillocactus schenckii (Cactaceae) in the Tehuacán Valley, Central Mexico. Economic Botany 63:375-387

Blancas J, Casas A, Pérez-Salicrup D, Caballero J, Vega E (2013) Ecological and socio-cultural factors influencing plant management in Náhuatl communities of the Tehuacán Valley, Mexico. Journal of Ethnobiology and Ethnomedicine 9:1-22

Blancas J, Casas A, Rangel-Landa S, Moreno-Calles A, Torres I, Pérez-Negrón E, Solís L, Delgado-Lemus A, Parra F, Arellanes Y, Caballero J, Cortés L, Lira R, Dávila P (2010) Plant Management in the Tehuacán-Cuicatlán Valley, Mexico. Economic Botany 64:287-302

Bridgewater PB (2002) Biosphere reserves: Special places for people and nature. Environmental Science and Policy 5:9-12

Brondizio ES, Settele J, Díaz S, Ngo HT (2019) IPBES (2019): Global assessment report on biodiversity and ecosystem services of the Intergovernmental Science-Policy Platform on Biodiversity and Ecosystem Services. Bonn.

Bvenura C, Sivakumar D (2017) The role of wild fruits and vegetables in delivering a balanced and healthy diet. Food Research International 99:15-30

Canale A, Ladio A (2020) La recolección de piñones de Pewén (Araucaria araucana): una situación significativa que conecta a niños mapuches con la naturaleza. Gaia Scientia 14:12-32

Capparelli A, Hilgert N, Ladio A, Lema VS, Llano C, Molares S, Pochettino ML, Stampella P (2011) 
Paisajes culturales de Argentina: Pasado y presente desde las perspectivas etnobotánica y paleoetnobotánica. Rev. de la Asoc. Argent. Ecol. Paisajes 2:67-79

Casas A, Caballero J, Mapes C, Zárate S (1997) Manejo de la vegetación y domesticación de plantas y origen de la agricultura en Mesoamérica. Boletín de la Sociedad Botánica de México 61:31-47

Casas A, Otero-Arnaiz A, Pérez-Negrón E, ValienteBanuet A (2007) In situ management and domestication of plants in Mesoamerica. Annals of Botany 100:1101-1115

Casas A, Torres-Guevara J, Parra F (Eds) (2017) Domesticación en el continente americano. Volumen 2. Editorial Morevalladolid, Morelia. Casas A, Vásquez MC, Viveros JL, Caballero J (1996) Plant management among Nahua and the Mixtec from the Balsas River Basin: and ethnobotanical approach to the study of plant domestication. Human Ecology 24:455-478

Chamorro MF, Ladio AH (2020) Native and exotic plants with edible fleshy fruits utilized in Patagonia and their role as sources of local functional foods. BMC Complementary Medicine and Therapies 20:1-16

Chamorro MF, Ladio AH, Molares S (2018) Patagonian Berries: An ethnobotanical approach to exploration of their nutraceutical potential. In: Martínez J, Muñoz-Acevedo A, Rai M (eds) Ethnobotany: Local Knowledge and Traditions. CRC Press, Boca Raton, pp. 50-69

Chamorro MF, Reiner G, Theoduloz C, Ladio A, Schmeda-Hirschmann G, Gómez-Alonso S, JiménezAspee F (2019) Polyphenol Composition and (Bio)Activity of Berberis Species and Wild Strawberry from the Argentinean Patagonia. Molecules 24:1-24

Clement CR (1999) 1492 and the loss of amazonian crop genetic resources. I. The relation between domestication and human population decline. Economic Botany 53:188.

Cornara L, La Rocca A, Terrizzano L, Dente F, Mariotti MG (2014) Ethnobotanical and phytomedical knowledge in the North-Western Ligurian Alps. Journal of Ethnopharmacology 155:463-484

Correa MN (1971) Flora Patagónica. Compositae. Colecciones Científicas del INTA, Buenos Aires

Correa MN (1984) Flora Patagónica. Dicotiledoneas dialipétalas (Droseraceae a Legu- minosae). Instituto nacional de Tecnología Agropecuaria., Buenos Aires

Correa MN (1988) Flora Patagónica. Dicotiledóneas, dialipétalas (Oxalidaceae a Cornaceae). Colecciones Científicas del INTA, Buenos Aires

Correa MN (1998) Flora Patagónica. Introducción. Colecciones Científicas del INTA, Buenos Aires

Crawley MJ (2013) The R book. Second ed. Jhon Wiley and Sons, Chichester

Cruse-Sanders J, Casas A (2017) Impactos evolutivos de las actividades humanas sobre las plantas: manejo, domesticación y conservación in situ y ex situ. In: Casas A, Torres-Guevara J, Parra F (eds) Domesticación en el continente americano. Second ed. Editorial Morellavalladolid, Morelia, pp. 451-473

Damascos MA, Prado CHB, Ladio AH, Arribere MA, Guevara SR (2005) Consequences of the elimination of old leaves upon spring phenological events and the new leaves nutrient concentration in a wintergreen woody species in the Southern hemisphere. Plant Ecology 181:1-8

de Mösbach EW (1992) Botánica indígena de Chile. Ed. Andrés Bello, Santiago de Chile

Díaz S, Pascual U, Stenseke M, Martín-López B, Watson RT, Molnár Z, Hill R, Chan KMA, Baste IA, Brauman KA, Polasky S, Church A, Lonsdale M, Larigauderie A, Leadley PW, van Oudenhoven APE, van der Plaat F, Schröter M, Lavorel S, AumeeruddyThomas Y, Bukvareva E, Davies K, Demissew S, Erpul G, Failler P, Guerra CA, Hewitt CL, Keune H, Lindley S, Shirayama Y (2018) Assessing nature's contributions to people. Science 359:270-272

Ezcurra C, Brion C (2005) Plantas del Nahuel Huapi. Catálogo de la flora vascular del Parque Nacional Nahuel Huapi, Argentina. Universidad Nacional del Comahue- Red Latinoamericana de Botánica, Bariloche

Fernández N (2007) Plantas exóticas invasoras de los parques nacionales de Patagonia. Universidad Nacional del Comahue, Bariloche

Fowler C, Lepofsky D (2011) Traditional Resource and Environmental Management. In: Anderson E, Pearsall D, Hunn E, Turner N (eds) Ethnobiology. Wiley-Blackwell, Chichester, p. 400

Furlan V, Pochettino ML, Hilgert NI (2017) Management of Fruit Species in Urban Home Gardens of Argentina Atlantic Forest as an Influence for Landscape Domestication. Frontiers in 


\section{Plant Science 8:1-12}

Giusti M, Svane U, Raymond CM, Beery TH (2018) A framework to assess where and how children connect to nature. Frontiers in Psychology 8:1-21

González-Insuasti MS, Caballero J (2007) Managing plant resources: How intensive can it be? $\mathrm{Hu}-$ man Ecology 35:303-314

González-Insuasti MS, Martorell C, Caballero J (2008) Factors that influence the intensity of non-agricultural management of plant resources. Agroforestry Systems 74:1-15

González-Soberanis C, Casas A (2004) Traditional management and domestication of tempesquistle, Sideroxylon palmeri (Sapotaceae) in the Tehuacán-Cuicatlán Valley, Central Mexico. Journal of Arid Environments 59:245-258

Grasser S, Schunko C, Vogl CR (2012) Gathering "tea" - from necessity to connectedness with nature. Local knowledge about wild plant gathering in the Biosphere Reserve Grosses Walsertal (Austria). Journal of Ethnobiology and Ethnomedicine 8:1-23

Hajduk A, Albornoz AM, Lezcano MJ (2008) Arqueología del Parque Nacional Nahuel Huapi (Provincia de Río Negro y Neuquén). Las ocupaciones tempranas de la transición Pleistoceno-Holoceno al Holoceno Medio en el área boscosa-lacustre. Cuartas Jornadas de Historia de la Patagonia.1:1-17

Ladio AH (2001) The Maintenance of Wild Edible Plant Gathering in a Mapuche Community of Patagonia. Economic Botany 55:243-254

Ladio AH (2017) Panorama etnoecológico de a pequeña horticultura familiar en enclaves rurales y urbanos del centronorte de a Patagonia. In: Duarte Almada E, Olveira e Souza M (eds) Quintais, Memória, resistência e patrimônio biocultural. EdUMEG, Belo Horizonte, pp. 139-157

Ladio AH, Damascos MA (2000) La invasión de plantas exóticas y la conservación de plantas nativas en baldíos suburbanos. Medio Ambiente $13: 27-34$

Ladio AH, Lozada M (2004) Patterns of use and knowledge of wild edible plants in distinct ecological environments: A case study of a Mapuche community from northwestern Patagonia. Biodiversity and Conservation 13:1153-1173

Ladio AH, Molares S (2017) Etnoconservacionismo y prácticas locales en Patagonia: avances y perspectivas. In: Casas A, Torres-Guevara J, Parra
Rondinel F (eds) Domesticación en el continente americano: Investigación para el manejo sustentable de recursos genéticos en el Nuevo Mundo. First ed. Editorial Morellavalladolid, Morelia, México., pp. 391-411

Lambaré DA, Vignale ND, Pochettino ML (2015) Las ferias y festivales regionales como instancia de reafirmación del patrimonio biocultural en la quebrada de Humahuaca (Jujuy, Argentina): el intercambio de duraznos (Prunus Persica). Gaia Scientia 9:7-16

Lins Neto EMDF, Peroni N, Casas A, Parra F, Aguirre X, Guillén S, Albuquerque UP (2014) Brazilian and Mexican experiences in the study of incipient domestication. Journal of ethnobiology and ethnomedicine 10:1-12

Lockwood JL, Hoopes M, Marchetti M (2013) Invasion ecology. Second ed. Wiley-Blackwell, Chichester

Łuczaj Ł, Pieroni A (2016) Nutritional Ethnobotany in Europe: From Emergency Foods to Healthy Folk Cuisines and Contemporary Foraging Trends. In: Sánchez Mata M, Tardío J (eds) Mediterranean Wild Edible Plants: Ethnobotany and Food Composition Tables. Springer Science+Business Media, New York, pp. 33-56

Łuczaj Ł, Szymański WM (2007) Wild vascular plants gathered for consumption in the Polish countryside: A review. Journal of Ethnobiology and Ethnomedicine 3:1-22

Maffi L (2005) Linguistic, Cultural, and Biological Diversity. Annual Review of Anthropology 34:343-361

Medeiros PM, Ferreira WS, Ramos MA, Da Silva TC, Ladio AH, Albuquerque UP (2017) Why do people use exotic plants in their local medical systems? A systematic review based on Brazilian local communities. PLoS ONE 12:1-14

Milanesi LDS, Peroni N, dos Reis MS (2013) Use of the palm Euterpe edulis Martius in landscape units managed by migrants of German origin in Southern Brazil. Journal of Ethnobiology and Ethnomedicine 9:1-11

Molares S, Ladio A (2009) Ethnobotanical review of the Mapuche medicinal flora: Use patterns on a regional scale. Journal of Ethnopharmacology 122:251-260

Nuñez MA, Simberloff D (2005) Invasive species and the cultural keystone species concept. Ecology and Society 10:4-7

Ochoa J, Moncunill ELN, Puntieri J, Güenuleo BS, 
Stefe SE, Cardozo ML, Neranzi Barriga F, Martinez EE, Torrego S, Naon S (2019) Saberes locales y frutos comestibles de plantas nativas en la comarca andina del paralelo $42^{\circ}$ (patagonia, argentina). Ethnoscientia 4:1-9

Parra F, Blancas JJ, Casas A (2012) Landscape management and domestication of Stenocereus pruinosus (Cactaceae) in the Tehuacan Valley: human guided selection and gene flow. Journal of Ethnobiology and Ethnomedicine 8:32

Parra F, Casas A, Peñaloza-Ramírez JM, CortésPalomec A, Rocha-Ramírez V, González-Rodríguez A (2010) Evolution under domestication: Ongoing artificial selection and divergence of wild and managed Stenocereus pruinosus (Cactaceae) populations in the Tehuacán Valley, Mexico. Annals of Botany 106:483-496

Pfeiffer JM, Voeks RA (2008) Biological invasions and biocultural diversity: Linking ecological and cultural systems. Environmental Conservation 35:281-293

R Core Team (2019) R: A Language and Environment for Statistical Computing. Vienna, Austria, R Foundation for Statistical Computing.

Reis M, Montagna T, Mattos AG, Filippon S, Ladio AH, Marques ADC, Zechini A, Peroni A, Mantovani A (2018) Domesticated Landscapes in Araucaria Forests, Southern Brazil: A Multispecies Local Conservation-by-Use System. Frontiers in Ecology and Evolution 6:1-14

Reyes-García V, Guèze M, Luz AC, Paneque-Gálvez J, Macía MJ, Orta-Martínez M, Pino J, RubioCampillo X (2013) Evidence of traditional knowledge loss among a contemporary indigenous society. Evolution and Human Behavior 34:249-257.

Richardson DM, Pyšek P, Rejmánek M, Barbour MG, Dane Panetta F, West CJ (2000) Naturalization and invasion of alien plants: Concepts and definitions. Diversity and Distributions 6:93-107

Richeri M, Cardoso MB, Ladio AH (2013) Soluciones locales y flexibilidad en el conocimiento ecológico tradicional frente a procesos de cambio ambiental: estudios de caso en Patagonia. Ecología Austral 23:184-193

Sansanelli S, Ferri M, Salinitro M, Tassoni A (2017) Ethnobotanical survey of wild food plants traditionally collected and consumed in the Middle Agri Valley (Basilicata region, southern Italy). Journal of Ethnobiology and Ethnomedicine 13:1-10
Schmeda-Hirschmann G, Jiménez-Aspee F, Theoduloz C, Ladio A (2019) Patagonian berries as native food and medicine. Journal of Ethnopharmacology 241:

Schunko C, Grasser S, Vogl CR (2012) Intracultural variation of knowledge about wild plant uses in the Biosphere Reserve Grosses Walsertal (Austria). Journal of Ethnobiology and Ethnomedicine 8:1-11

Schunko C, Grasser S, Vogl CR (2015) Explaining the resurgent popularity of the wild: Motivations for wild plant gathering in the Biosphere Reserve Grosses Walsertal, Austria. Journal of Ethnobiology and Ethnomedicine 11: 1-14

Sedrez dos Reis M, Ladio A, Peroni N (2014) Landscapes with Araucaria in South America: Evidence for a cultural dimension. Ecology and Society 19:43

Shackleton RT, Larson BMH, Novoa A, Richardson DM, Kull CA (2019) The human and social dimensions of invasion science and management. Journal of Environmental Management 229:1-9

Sieber S, da Silva TC, Zenóbia de Oliveira Campos L, Zank S, Albuquerque UP (2014) Participatory Methods in Ethnobiological and Ethnoecological Research. In: Albuquerque UP (ed) Methods and Techniques in Ethnobiology and Ethnoecology. Springer, New York, pp. 39-58

Soto-Covasich J, Reyes-Farias M, Torres RF, Vasquez K, Duarte L, Quezada J, Jimenez P, Pino MT, Garcia-Nannig L, Mercado L, Garcia-Diaz DF (2020) A polyphenol-rich Calafate (Berberis microphylla) extract rescues glucose tolerance in mice fed with cafeteria diet. Journal of Functional Foods 67:1-9

Sousa Júnior JR, Collevatti RG, Lins Neto EMF, Peroni N, Albuquerque UP (2016) Traditional management affects the phenotypic diversity of fruits with economic and cultural importance in the Brazilian Savanna. Agroforestry Systems 92:11-21

Stampella PC, Lambaré DA, Hilgert NI, Pochettino ML (2013) What the Iberian conquest bequeathed to us: The fruit trees introduced in argentine subtropic - Their history and importance in present traditional medicine. Evidence-based Complementary and Alternative Medicine 2013:1-17

Tardío J, Pardo-De-Santayana M (2008) Cultural importance indices: A comparative analysis based on the useful wild plants of southern Cantabria (northern Spain). Economic Botany 
62:24-39

Ticktin T (2004) The ecological implications of harvesting non-timber forest products. Journal of Applied Ecology 41:11-21

Ticktin T (2015) The ecological sustainability of non-timber forest product harvest: principles and methods. In: Shackleton CM (ed) Ecological Sustainability for Non-timber Forest Products. Taylor \& Francis, Oxfordshire, pp. 31-53

UNESCO (2010) Man and the Biosphere (MAB) Programme. Final Report, Paris https://en.unesco.org/mab.

Viña A, García Frapolli E, Hussain S, Merino L, Akong Minang P, Nagabhatla N, Bavanera P, Pfaff A (2019) Status and trends; indirect and direct drivers of change. The IPBES Global Assessment on Biodiversity and Ecosystem Services. pp. 1-245

Wadt LHO, Kainer KA, Staudhammer CL, Serrano ROP (2008) Sustainable forest use in Brazilian extractive reserves: Natural regeneration of Brazil nut in exploited populations. Biological Conservation 141:332-346

Zimmermann H, Brandt P, Fischer J, Welk E, von Wehrden H (2014) The Human Release Hypoth- esis for biological invasions: Human activity as a determinant of the abundance of invasive plant species. F1000Research 3:1-13

Zimmermann H, Von Wehrden H, Damascos MA, Bran D, Welk E, Renison D, Hensen I (2011) Habitat invasion risk assessment based on Landsat 5 data, exemplified by the shrub Rosa rubiginosa in southern Argentina. Austral Ecology $36: 870-880$

Zuur AF, Ieno EN (2016) A protocol for conducting and presenting results of regressiontype analyses. Methods in Ecology and Evolution 7:636-645

Zuur AF, Ieno EN, Walker NJ, Saveliev AA, Smith GM (2009) Mixed effects models and extensions in ecology with R. Springer Science+Business Media, New York

Received: 06 July 2020

Accepted: 28 September 2020

Published: 10 February 2021 


\section{Additional Files}


Add File 1. Species used in Cuyin Manzano and their main variables.

\begin{tabular}{|c|c|c|c|c|c|}
\hline Species & $\overline{\mathrm{CU}}$ & Managment practice & NPMs & IM & Origin \\
\hline Aristotelia chilensis (Molina) Stuntz & 91 & gathering & 7 & 0.64 & $\overline{\mathrm{na}}$ \\
\hline Berberis empetrifolia Lam. & 73 & gathering & 7 & 0.64 & na \\
\hline Berberis microphylla G.Forst. & 100 & gathering, tolerance & 15 & 1.73 & na \\
\hline Berberis microphylla G.Forst. Calafate & 36 & & 0 & 0 & na \\
\hline Berberis serratodentata Lechl. & 64 & gathering & 3 & 0.27 & na \\
\hline Cydonia oblonga Mill. & 45 & $\begin{array}{l}\text { protection, sowing, transplanta- } \\
\text { tion }\end{array}$ & 6 & 2.64 & ex \\
\hline Ephedra chilensis C.Presl & 36 & gathering & 2 & 0.18 & na \\
\hline $\begin{array}{l}\text { Fragaria } \times \text { ananassa (Duchesne ex We- } \\
\text { ston) Duchesne ex Rozier }\end{array}$ & 18 & protection, transplantation & 4 & 1.64 & ex \\
\hline Fragaria chiloensis (L.) Mill. & 100 & $\begin{array}{l}\text { gathering, protection, transplan- } \\
\text { tation }\end{array}$ & 14 & 2.36 & na \\
\hline $\begin{array}{l}\text { Gaultheria mucronata (L.f.) Hook. \& } \\
\text { Arn. }\end{array}$ & 64 & gathering & 7 & 0.64 & na \\
\hline Malus domestica Borkh. & 82 & $\begin{array}{l}\text { gathering, protection, care of in- } \\
\text { herited plant, transplantation }\end{array}$ & 20 & 4.91 & ex \\
\hline Malus sylvestris (L.) Mill. & 55 & gathering & 3 & 0.27 & na \\
\hline Prunus avium (L.) L. & 64 & $\begin{array}{l}\text { gathering, protection, care of in- } \\
\text { herited plant, transplantation }\end{array}$ & 8 & 2.91 & ex \\
\hline Prunus cerasus L. & 82 & $\begin{array}{l}\text { gathering, protection, care of in- } \\
\text { herited plant, transplantation }\end{array}$ & 17 & 4.91 & ex \\
\hline Prunus domestica L. & 55 & $\begin{array}{l}\text { gathering, protection, care of in- } \\
\text { herited plant, transplantation }\end{array}$ & 10 & 3.82 & ex \\
\hline Prunus persica (L.) Batsch var. persica & 18 & $\begin{array}{l}\text { protection, sowing, transplanta- } \\
\text { tion }\end{array}$ & 4 & 1.55 & ex \\
\hline $\begin{array}{l}\text { Prunus persica var. nectarina (Sol.) } \\
\text { Maxim }\end{array}$ & 9 & sowing & 1 & 0.45 & ex \\
\hline Pyrus communis L. & 45 & $\begin{array}{l}\text { gathering, protection, care of in- } \\
\text { herited plant, transplantation }\end{array}$ & 11 & 3.09 & ex \\
\hline Pyrus spp. & 9 & & 0 & 0 & ex \\
\hline Ribes aureum Pursh & 9 & $\begin{array}{l}\text { protection, sowing, transplanta- } \\
\text { tion }\end{array}$ & 3 & 1.27 & ex \\
\hline Ribes cucullatum Hook. \& Arn. & 18 & gathering & 1 & 0.09 & na \\
\hline Ribes magellanicum Poir. & 36 & gathering & 1 & 0.09 & na \\
\hline Ribes uva-crispa $\mathrm{L}$. & 45 & $\begin{array}{l}\text { gathering, protection, care of in- } \\
\text { herited plant, transplantation }\end{array}$ & 10 & 3.73 & ex \\
\hline Rosa rubiginosa $\mathrm{L}$. & 91 & gathering & 10 & 0.91 & ex \\
\hline Rubus idaeus L. & 55 & $\begin{array}{l}\text { protection, care of inherited } \\
\text { plant, transplantation }\end{array}$ & 9 & 3.73 & ex \\
\hline Rubus ulmifolius Schott & 18 & $\begin{array}{l}\text { protection, care of inherited } \\
\text { plant }\end{array}$ & 2 & 0.64 & ex \\
\hline Sambucus nigra L. & 73 & $\begin{array}{l}\text { gathering, protection, transplan- } \\
\text { tation }\end{array}$ & 12 & 3 & ex \\
\hline $\begin{array}{l}\text { Schinus patagonicus (Phil.) } \\
\text { Johnst. }\end{array}$ & 9 & gathering & 1 & 0.09 & na \\
\hline
\end{tabular}


Add File 2. Estimated regression parameters, standard errors, z-values and P-values for the models presented in Table 1.

\begin{tabular}{llcccc}
\hline \hline \multicolumn{1}{c}{ Model } & & Estimate & Std. Error & Z value & P value \\
\hline \hline A & (Intercept) & -182 & 289 & -632 & 533 \\
B (native) & originnative & 465 & 462 & 1007 & 0.323 \\
& (Intercept) & -1710 & 782 & -2179 & $<0.05$ \\
& Ghatering & 3160 & 863 & 3657 & $<0.05$ \\
& Tolerance & 693 & 987 & 702 & 482 \\
& Transplanting & 0 & 1110 & 0.00 & 1.00 \\
C (exotic) & (Intercept) & -348 & 289 & -1207 & 228 \\
& Protection & 10704 & 335 & 3200 & $<0.05$ \\
& Ghatering & 0.98 & 339 & 2898 & $<0.05$ \\
& Sowing & -10986 & 577 & -1903 & 57 \\
& Transplanting & 949 & 340 & 2792 & $<0.05$ \\
D (gathering) & (Intercept) & 693 & 317 & 2.19 & $<0.05$ \\
& originnative & 759 & 481 & 1.58 & 0.1142 \\
E (protection) & (Intercept) & 804 & 198 & 4057 & $<0.05$ \\
& originnative & -25091 & 748 & -3355 & $<0.05$ \\
F (transplanting) & (Intercept) & 722 & 222 & 3253 & $<0.05$ \\
& originnative & -24269 & 762 & -3183 & $<0.05$ \\
G & (Intercept) & -182 & 289 & -632 & 533 \\
\hline \hline
\end{tabular}

